\title{
Extraction-Chromogenic System for Cobalt Based on 5-Methyl-4-(2-thiazolylazo) Resorcinol and Benzalkonium Chloride
}

\author{
Danail G. Georgiev Hristov, ${ }^{1}$ Petya Vassileva Racheva, ${ }^{1,2}$ \\ Galya Konstantinova Toncheva ${ }^{3}$ and Kiril Blazhev Gavazov ${ }^{1,2, *}$ \\ ${ }^{1}$ Department of Chemical Sciences, Medical University of Plovdiv, 120 Buxton Brothers St., Plovdiv 4004, Bulgaria \\ ${ }^{2}$ Research Institute at the Medical University of Plovdiv, 15A Vasil Aprilov Bld., Plovdiv, Bulgaria \\ ${ }^{3}$ Department of General and Inorganic Chemistry with Methodology of Chemical Education, \\ University of Plovdiv Paisii Hilendarski, 24 Tsar Assen St., Plovdiv 4000, Bulgaria \\ *Corresponding author: E-mail: kgavazov@abv.bg
}

Received: 04-14-2020

\begin{abstract}
The interaction between $\mathrm{Co}^{\mathrm{II}}$ and 5-methyl-4-(2-thiazolylazo)-resorcinol (MTAR) was studied in a water-chloroform system, in the presence or absence of benzalkonium chloride (BZC) as a cationic ion-association reagent. The optimum $\mathrm{pH}$, concentration of the reagents and extraction time for the extraction of Co were found. In the presence of $\mathrm{BZC}$, the extracted ion-associate could be represented by the formula $\left(\mathrm{BZ}^{+}\right)\left[\mathrm{Co}^{\mathrm{III}}\left(\mathrm{MTAR}^{2-}\right)_{2}\right]$, where MTAR is in its deprotonated form. The following extraction-spectrophotometric characteristics were determined: absorption maximum, molar absorptivity, Sandell's sensitivity, limit of detection, limit of quantification, constant of extraction, distribution ratio and fraction extracted. In the absence of BZC, the extraction is incomplete and occurs in a narrow $\mathrm{pH}$ range. The extracted chelate contains one deprotonated and one monoprotonated ligand: $\left[\mathrm{Co}^{\mathrm{III}}\left(\mathrm{MTAR}^{2-}\right)\left(\mathrm{HMTAR}^{-}\right)\right]$.
\end{abstract}

Keywords: Cobalt; 4-(2-thiazolylazo)resorcinol; benzalkonium chloride; ternary complex; solvent extraction; spectrophotometry

\section{Introduction}

Cobalt is a group 9 transition metal that occupies position 27 in the periodic table. Because of its unique properties it is important for industry, agriculture, medicine and high technology development. As a highly wear- and corrosion-resistant metal which retains these properties even at high temperature, cobalt is an essential constituent of alloys for special uses. ${ }^{1,2}$ It is also applied in the manufacture of sintered cutting tools, catalysts, permanent magnets, pigments, siccative's and rechargeable (e.g., lithium-ion) batteries. Since the need of these batteries increases, some business experts predict a $47 \mathrm{x}$ increase in global demand for cobalt in 2030 compared to 2017.

Cobalt is a relatively rare element. It is present in rocks, soils and sea water at very low concentrations and its average content in the continental crust is approximately $17.3 \mathrm{mg} / \mathrm{kg}$. ${ }^{4}$ There are several commercially important cobalt-containing minerals, such as heterogenite, linnaeite, cobaltite, smaltite, erythrite, carrolite, skutterudite and asbolite. However, in most deposits, this element is not in sufficient quantity to be economically minable alone and is obtained as a by-product of the metallurgy of copper, nickel, silver, gold, lead and zinc. ${ }^{1,4,5}$

Cobalt is an essential trace element for all animals, including humans, and an active nutrient for bacteria, fungi and algae. It is utilized by animals only in the form of vitamin B-12, synthesized by certain bacteria and archaea in the presence of enough cobalt. Cobalt deficiency (or vitamin B-12 deficiency) in humans can lead to pernicious anemia and nerve damage. ${ }^{6}$ On the other hand, excess cobalt can provoke numerous negative effects on central metabolism. ${ }^{7,8}$ That is why its content in various samples should be monitored. ${ }^{8-11}$

There are many analytical methods for cobalt. Azo dyes such as 4-(2-pyridylazo)resorcinol (PAR) $)^{12-23}$ and 
4-(2-thiazolylazo)resorcinol (TAR) ${ }^{24-27}$ have long been used for its preconcentration and subsequent determination. Due to the ability of these reagents to form anionic chelates with cobalt cations, analytical procedures are often associated with the addition of auxiliary reagents providing the necessary hydrophobicity and extraction characteristics.

The following cationic reagents have been used as components of Co-PAR and Co-TAR ternary complexes: diphenylguanidine, ${ }^{15}$ dicyclohexyl-18-crown- $6,{ }^{17}$ tetradecyl(trihexyl)phosphonium chloride, ${ }^{21}$ xylometazoline hydrochloride, ${ }^{19}$ tributylammonium bromide, ${ }^{22}$ tetraphenylarsonium chloride, ${ }^{28,29}$ tetraphenylphosphonium chloride, ${ }^{28,29}$ nitron, ${ }^{30}$ tetrazolium salts, ${ }^{27,31-33}$ and quaternary ammonium salts. ${ }^{16,18,20,34-36}$

5-Methyl-4-(2-thiazolylazo)resorcinol (MTAR) ${ }^{37}$ is a TAR derivative that has been used in our laboratory for the liquid-liquid extraction of $\mathrm{V}^{\mathrm{IV}, \mathrm{V}} 38-42$ and $\mathrm{Ni}^{\mathrm{II}} .{ }^{43}$ Its interaction with $\mathrm{Co}^{\mathrm{II}}$ in water-ethanol medium has been studied by Kiryukhina. ${ }^{44}$ This reagent has also been used for the reversed-phase capillary high-performance liquid chromatographic determination of $\mathrm{Co}^{\mathrm{II}}$. ${ }^{45}$ There are no reports on the liquid-liquid extraction of Co complexes with MTAR, nor on the ternary Co-MTAR complexes with auxiliary reagents.

The objective of this work was to investigate the complex formation and liquid-liquid extraction of Co with MTAR in the presence and absence of benzalkonium chloride (BZC). BZC (Figure 1) is a mixture of quaternary ammonium chlorides used in pharmaceuticals, cosmetics and cleaning products due to its valuable bacteriostatic, bactericidal, fungicidal, algicide, spermicide and surfactant properties. ${ }^{46,47}$ Its ability to form ion-pairs with bulky anions has been used in liquid-liquid extraction methods for its determination. ${ }^{48}$

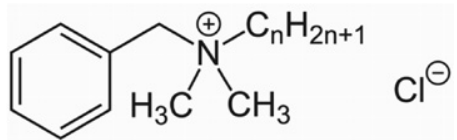

Fig. 1. Structural formula of BZC. The index $\mathrm{n}$ can be $8,10,12,14$, 16 or 18 (constituents with $\mathrm{n}=12,14$, and 16 predominate).

\section{Experimental}

\section{1. Reagents and Apparatus}

Cobalt standard solution $\left(1000 \mathrm{mg} \mathrm{dm}^{-3}, \mathrm{Co}\left(\mathrm{NO}_{3}\right)_{2}\right)$ was obtained from Merck, Germany. Working solutions
$\left(c_{\mathrm{Co}}=4.0 \times 10^{-4} \mathrm{~mol} \mathrm{dm}^{-3}\right)$ were prepared by appropriate dilution. MTAR (95\%) and BZC ( $\geq 95 \%)$ were also Merck products. Neutral or slightly basic aqueous solutions of MTAR $\left(2.0 \times 10^{-3} \mathrm{~mol} \mathrm{dm}^{-3}\right)$ were prepared by the addition of $\mathrm{KOH} .{ }^{40,41} \mathrm{BZC}$ was dissolved in water $\left(c_{\mathrm{BZC}}=2 \times\right.$ $10^{-2} \mathrm{~mol} \mathrm{dm}^{-3}$ and $4 \times 10^{-4} \mathrm{~mol} \mathrm{dm}^{-3}$ ). Chloroform was redistilled and used repeatedly. The acidity of the aqueous phase was maintained constant by the addition of buffer solution, prepared by mixing $2 \mathrm{~mol} \mathrm{\textrm {dm } ^ { - 3 }}$ aqueous solutions of acetic acid and ammonia. The resulting $\mathrm{pH}$ was checked by a WTW InoLab $720 \mathrm{pH}$-meter (Germany) with a precision of $\pm 0.01 \mathrm{pH}$ units. UV/vis spectrophotometers Ultrospec 3300 pro and Camspec M508 UV-Vis (UK), equipped with $10-\mathrm{mm}$ path-length cells, were employed for absorbance measurements. Distilled water was used in all experiments.

\section{2. General Procedure}

Solutions of $\mathrm{Co}^{\mathrm{II}}$, buffer ( $\mathrm{pH}$ 3.7-9.2), MTAR and BZC were sequentially transferred into a separatory funnel. Water was added to a total volume of $10 \mathrm{~cm}^{3}$. Then 10 $\mathrm{cm}^{3}$ of chloroform were buretted and the funnel was shaken for a fixed time interval. After a short wait for phase separation, a portion of the organic extract was transferred through a filter paper into the spectrophotometer cell. Absorbance was measured against chloroform or a simultaneously prepared blank.

\section{3. Determination of the Distribution Ratio and Fraction Extracted}

The distribution ratio $D$ was found from the equation $D=A_{1} /\left(A_{3}-A_{1}\right)$, where $A_{1}$ is the absorbance measured after a single extraction under the optimum conditions in the presence of BZC (Table 1) and $A_{3}$ is the absorbance measured after a triple extraction under the same conditions. The total volume in both cases (single extraction and triple extraction) was $25 \mathrm{~cm}^{3}{ }^{39-41}$ The fraction extracted was calculated from the equation $E(\%)=100 \times D /(D+1)$.

\section{Results and Discussion}

\section{1. Absorption Spectra and Effect of $\mathrm{pH}$}

Kiryukhina ${ }^{44}$ reported that $\mathrm{Co}^{\mathrm{II}}$ reacts with MTAR in a water-ethanol medium to form a 1:2-complex with an

Table 1. Optimum extraction-spectrophotometric conditions.

\begin{tabular}{lcccc}
\hline Extraction system & $\begin{array}{c}\lambda_{\text {max }} \\
\mathbf{n m}\end{array}$ & $\mathbf{p H}$ & $\begin{array}{c}c_{\text {MTAR }}, \\
\mathbf{m o l ~ d m}^{-3}\end{array}$ & $\begin{array}{c}c_{\mathrm{BZC}}, \begin{array}{c}\text { Shaking } \\
\mathbf{m o l ~ d m}^{-3}\end{array} \\
\text { time, min }\end{array}$ \\
\hline Co - MTAR - water - chloroform & 509 & 5.5 & $4.0 \times 10^{-4}$ & - \\
Co - MTAR - BZC- water - chloroform & 550 & 7.5 & $1.6 \times 10^{-4}$ & $1.4 \times 10^{-4}$ \\
\hline
\end{tabular}

${ }^{\text {a }}$ quantitative extraction cannot be achieved 
absorption maximum $\lambda_{\max }=520 \mathrm{~nm}$. She found that the optimum $\mathrm{pH}$ for complex formation was $6-8$ but did not pay attention to the change in spectral characteristics as the $\mathrm{pH}$ changed.

Our extraction studies have shown that the extracted into organic phase complex in the Co-MTAR-water-chloroform system has an absorption maximum at $509 \mathrm{~nm}$ (Figure 2, spectrum 1). In the presence of BZC, the absorption maximum shifts to the higher wavelengths (about 549 $-550 \mathrm{~nm}$; spectrum 2) and the optimum $\mathrm{pH}$ range widens significantly and shifts to higher $\mathrm{pH}$ values (Figure 3 ).

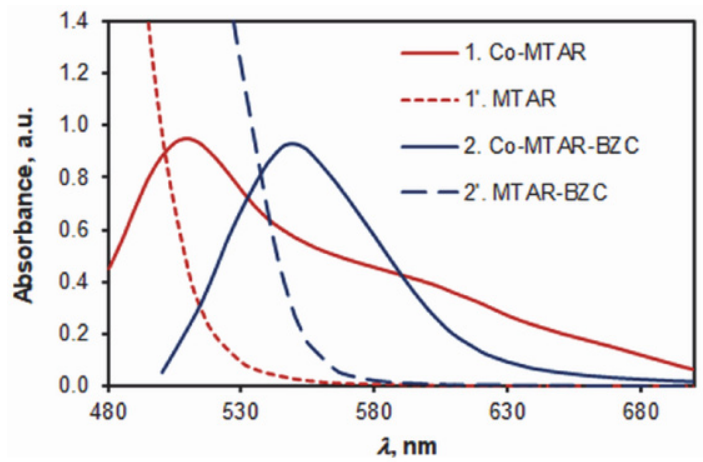

Figure 2. Absorption spectra in chloroform of the Co-MTAR binary complex (1) against blank ( $1^{\prime}$ ) and Co-MTAR-BZC ternary complex (2) against corresponding blank (2'). $c_{\mathrm{Co}}=4 \times 10^{-5} \mathrm{~mol} \mathrm{dm}^{-3} ; t_{\mathrm{ex}}=3$ $\min ; c_{\mathrm{MTAR}}=4.0 \times 10^{-4} \mathrm{~mol} \mathrm{dm}{ }^{-3}\left(1,1^{\prime}\right)$ or $1.6 \times 10^{-4} \mathrm{~mol} \mathrm{dm}^{-3}(2$, $\left.2^{\prime}\right) ; \mathrm{pH}=5.5\left(1,1^{\prime}\right)$ or $7.5\left(2,2^{\prime}\right) ; c_{\mathrm{BZC}}=1.4 \times 10^{-4} \mathrm{~mol} \mathrm{dm}^{-3}\left(2,2^{\prime}\right)$.

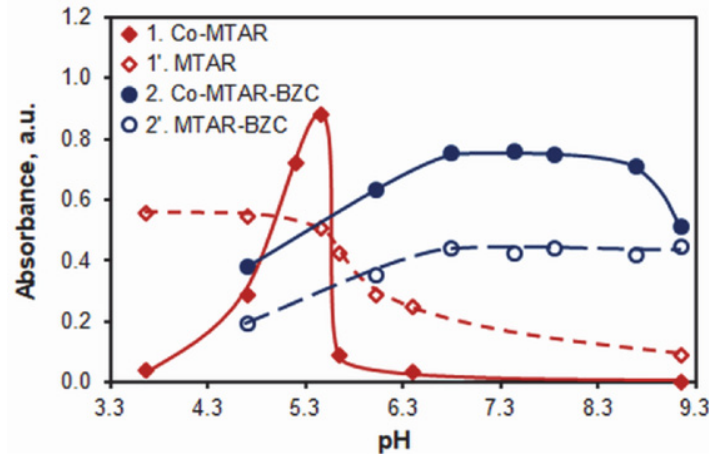

Figure 3. Absorbance of the Co-MTAR (1) and Co-MTAR-BZC (2) complexes and corresponding blanks (1' and $\left.2^{\prime}\right) v s \mathrm{pH}$ of the aqueous phase. $\mathrm{Co}_{\mathrm{O}}=4 \times 10^{-5} \mathrm{~mol} \mathrm{dm}^{-3}(1,2) ; c_{\mathrm{MTAR}}=4 \times 10^{-4} \mathrm{~mol} \mathrm{dm}^{-3}$ $\left(1,1^{\prime}, 2,2^{\prime}\right) ; c_{\mathrm{BZC}}=1 \times 10^{-3} \mathrm{~mol} \mathrm{dm}^{-3}\left(2,2^{\prime}\right) ; \lambda=509 \mathrm{~nm}\left(1,1^{\prime}\right)$ or 550 $\mathrm{nm}\left(2,2^{\prime}\right) ; t_{\mathrm{ex}}=3 \mathrm{~min}$.

\section{2. Effect of MTAR Concentration and the MTAR-to-Co Molar Ratio}

The effect of MTAR concentration on the absorbance at 509 and $550 \mathrm{~nm}$ is shown in Figure 4, curves 1a-c. Processing of the data received in the presence or absence of BZC by the straight-line method of Asmus ${ }^{49}$ (Figure 5) showed that in both cases the MTAR-to-Co molar ratio is $2: 1$. When the concentration of MTAR increases in the

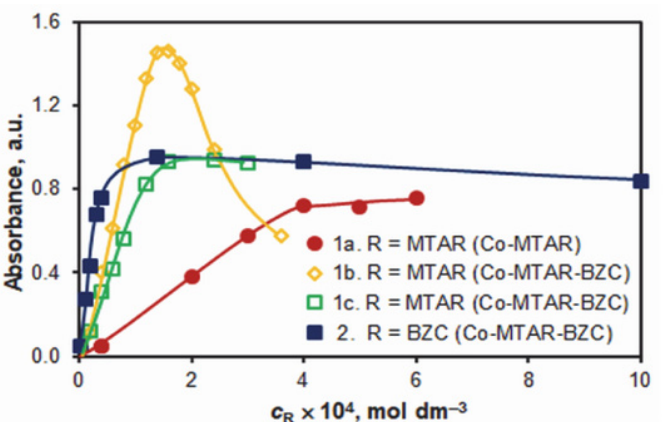

Figure 4. Effect of MTAR (1a,b,c) and BZC (2) concentration. (1a) $c_{\mathrm{Co}}=4 \times 10^{-5} \mathrm{~mol} \mathrm{dm}^{-3}$, pH 5.2, $t_{\mathrm{ex}}=3 \mathrm{~min}, \lambda=509 \mathrm{~nm} ;(1 \mathrm{~b}) c_{\mathrm{Co}}=$ $8.5 \times 10^{-5} \mathrm{~mol} \mathrm{dm}^{-3}, c_{\mathrm{BZC}}=4 \times 10^{-4} \mathrm{~mol} \mathrm{dm}^{-3}, \mathrm{pH} 6.0, t_{\mathrm{ex}}=3 \mathrm{~min}$, $\lambda=509 \mathrm{~nm} ;(1 \mathrm{c}) c_{\mathrm{Co}}=4.0 \times 10^{-5} \mathrm{~mol} \mathrm{dm}^{-3}, c_{\mathrm{BZC}}=1.4 \times 10^{-4} \mathrm{~mol}$ $\mathrm{dm}^{-3}, \mathrm{pH} 7.5, t_{\mathrm{ex}}=3 \mathrm{~min}, \lambda=550 \mathrm{~nm} ;(2) c_{\mathrm{Co}}=4 \times 10^{-5} \mathrm{~mol} \mathrm{dm}^{-3}$,

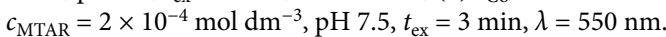

a)

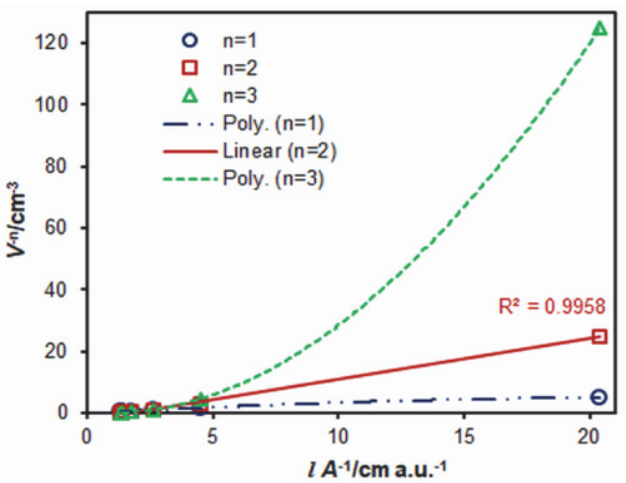

b)

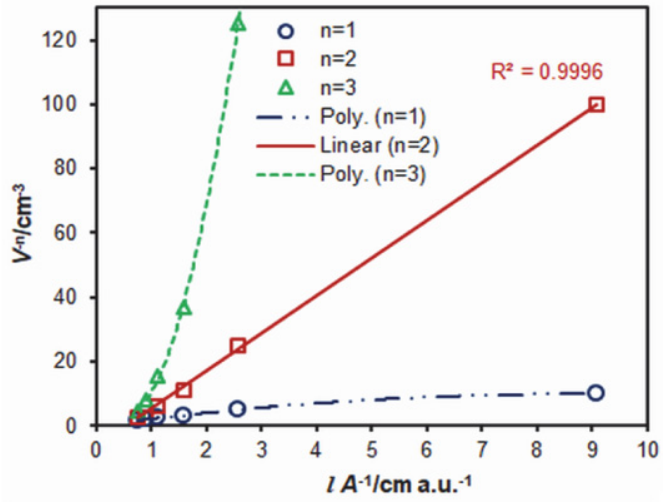

c)

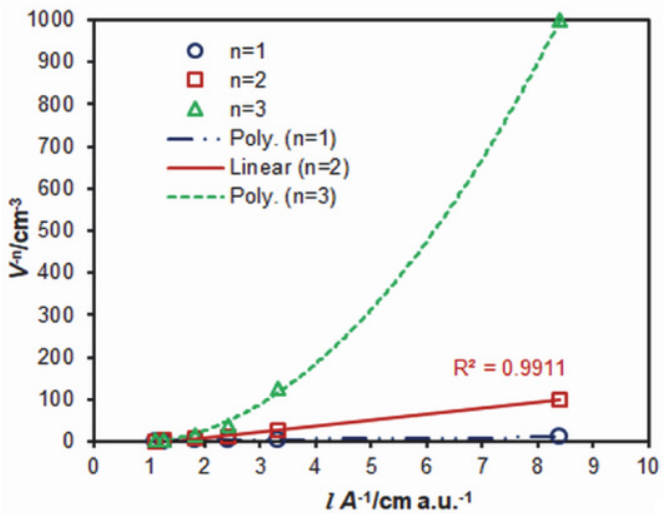

Figure 5. Determination of the MTAR-to-Co molar ratio by the straight-line method of Asmus. The experimental conditions are given in Figure 4, curves 1a-c, respectively. 
presence of BZC, the absorption maximum shifts to lower wavelengths. This can be attributed to the simultaneous extraction of the binary Co-MTAR complex $\left(\lambda_{\max }=509 \mathrm{~nm}\right)$.

\section{3. Effect of BZC Concentration and the BZC-to-Co Molar Ratio}

The effect of BZC concentration is shown in Figure 4 , curve 2 . This curve allowed the BZC-to-Co molar ratio (1:1) to be determined by many methods: straight-line method of Asmus, ${ }^{49}$ Bent and French limited logarithm $\operatorname{method}^{50,51}$ (Figure 6), You and Jones method ${ }^{52}$ (Figure 7) and mobile equilibrium method ${ }^{53}$ (Figure 8). Successful determination of the composition by all these methods is rarely possible since they have certain limitations related to the stability of the species and the presence of side processes. ${ }^{51,54}$

In addition to the aforementioned methods, the composition was determined by the Job's method of continuous variations (Figure 9). ${ }^{55}$ The obtained curve shows that the complex is rather stable.

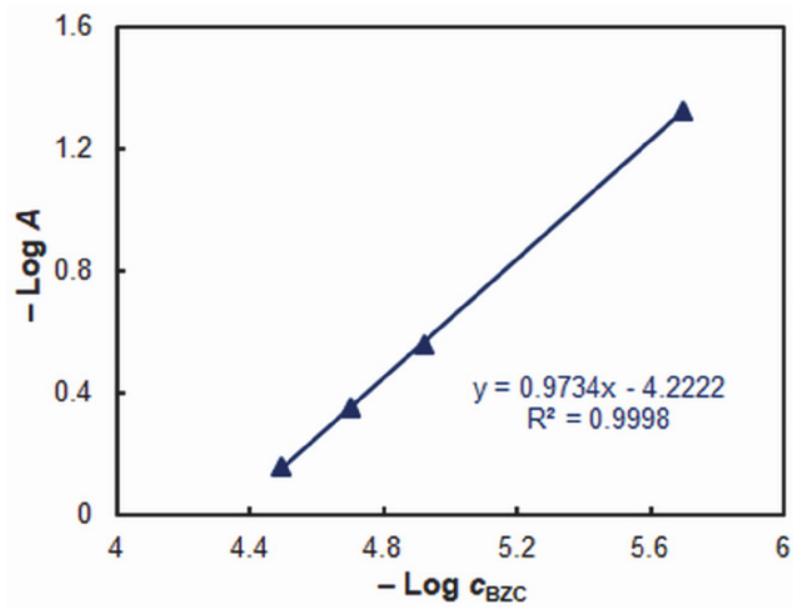

Figure 6. Determination of the BZC-to-Co molar ratio by the BentFrench limited logarithm method.

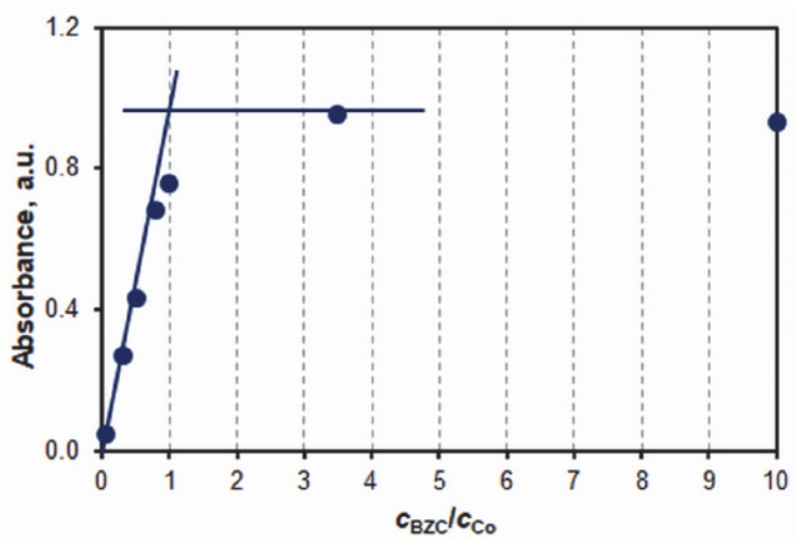

Figure 7. Determination of the BZC-to-Co molar ratio by the You and Jones method.

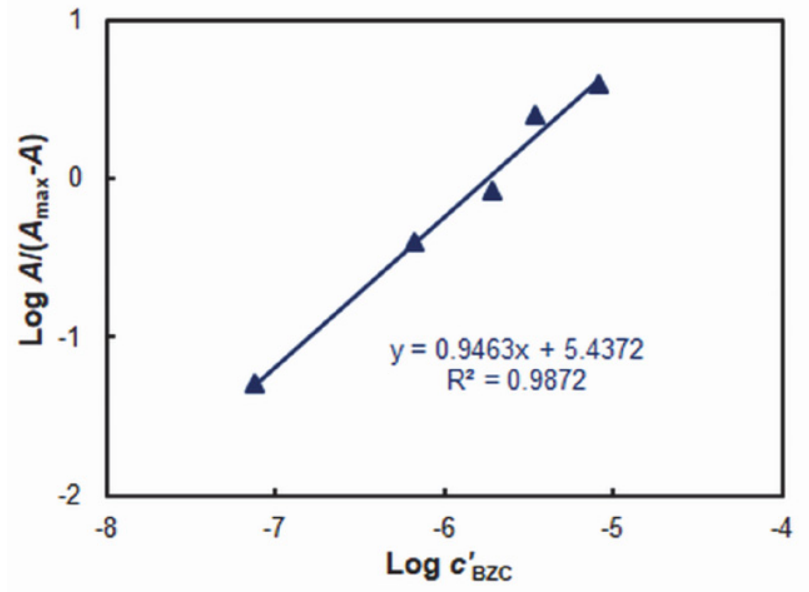

Figure 8. Determination of the BZC-to-Co molar ratio by the mobile equilibrium method.

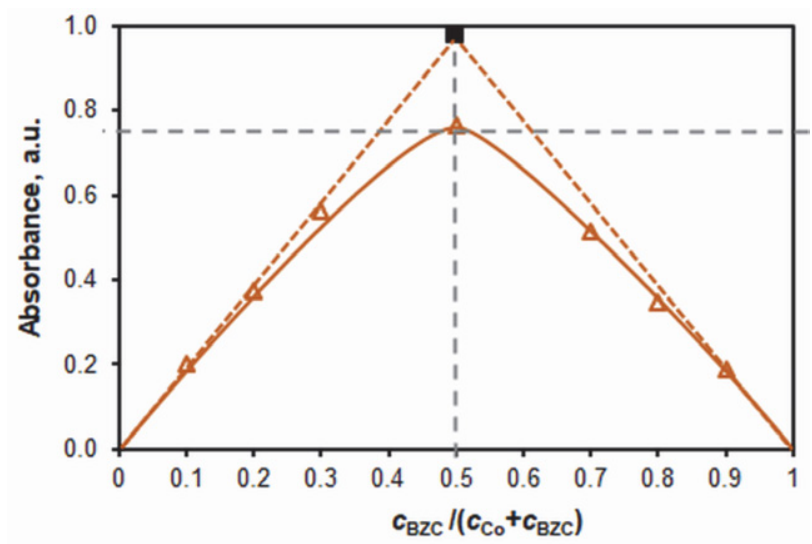

Figure 9. Determination of the BZC-to-Co molar ratio by the Job's method of continuous variations and $K_{\mathrm{ex}}$ by the Likussar-Boltz method. $k=c_{\mathrm{Co}}+c_{\mathrm{BZC}}=8 \times 10^{-5} \mathrm{~mol} \mathrm{dm}{ }^{-3}, c_{\mathrm{MTAR}}=2 \times 10^{-4} \mathrm{~mol}$ $\mathrm{dm}^{-3}, \mathrm{pH} 7.5, \lambda=547 \mathrm{~nm}$.

\section{4. Suggested Chemical Formulae and Equations}

In order to propose correct formulae for the extracted species, the data for their composition must be synchronized with the information accumulated in the literature for the possible oxidation of $\mathrm{Co}^{\mathrm{II}}$ to $\mathrm{Co}^{\mathrm{III}}$ by the atmospheric oxygen. Numerous studies in this area allow us to summarize that in the presence of azo dyes ${ }^{17,27-31,56-61}$ such as PAR and TAR, (i) the oxidation proceeds rapidly (in seconds); $; 8,61$ (ii) the oxidation is quantitative; ${ }^{60}$ (iii) $\mathrm{Co}^{\mathrm{II}}$ is oxidized even in the presence of reducing agents such as ascorbic acid, sulfite or hydrazine; ${ }^{57,61}$ (iv) the protonation state of the azo dye in the complex can be estimated by the position and intensity of the spectral bands in the visible range.

The MTAR complex extracted in the absence of BZC has a composition of Co:MTAR $=1: 2$. Because of the requirement of electroneutrality, it is reasonable to assume that its formula is $\left[\mathrm{Co}^{\mathrm{III}}\left(\mathrm{HL}^{-}\right)\left(\mathrm{L}^{2-}\right)\right]^{0}\left(\mathrm{~L}^{2-}\right.$ and $\mathrm{HL}^{-}$are the deprotonated and monoprotonated forms of the ligand $\mathrm{H}_{2} \mathrm{~L}=$ MTAR). A similar Co-PAR complex has been isolat- 
ed and studied by Mochizuki et al. ${ }^{58}$ The chloroform-extracted (at $\mathrm{pH}$ close to 4 ) Co-TAR binary complex ${ }^{29}$ can probably be represented by the same formula.

It can be seen from Figure 3 (curve 1) that the CoMTAR binary complex is formed in a narrow $\mathrm{pH}$ range (about pH 5.5), which corresponds well with the onset of the decrease in absorbance (curve 1 ') associated with the conversion of the neutral MTAR into a monoanion:

$$
\mathrm{H}_{2} \mathrm{~L}^{0} \rightleftarrows \mathrm{HL}^{-}+\mathrm{H}^{+}
$$

The course of curve 1' is in good agreement with the $\mathrm{p} K_{\mathrm{a}}$ value determined by Menek et al. ${ }^{62}\left(\right.$ Table $2 ; \mathrm{p} K_{\mathrm{p}-\mathrm{OH}}=$ 5.7), characterizing Eq. 1.

As the $\mathrm{pH}$ increases the neutral complex is transformed into an anionic complex with a bathochromically shifted absorption maximum:

$$
\left[\mathrm{Co}+\mathrm{III}\left(\mathrm{HL}^{-}\right)\left(\mathrm{L}^{2-}\right)\right]^{0} \rightleftarrows\left[\mathrm{Co}^{\mathrm{III}}\left(\mathrm{L}^{2-}\right)_{2}\right]^{-}+\mathrm{H}^{+}
$$

The anionic complex can also be formed by the direct interaction (Eq. 3) of the metal with the dominant form of the reagent under optimal conditions (i.e., $\mathrm{HL}^{-}$).

$$
\mathrm{Co}_{(\mathrm{aq})}^{\mathrm{II}}+2 \mathrm{HL}^{-} \rightleftarrows\left[\mathrm{Co}^{\mathrm{III}}\left(\mathrm{L}^{2-}\right)_{2}\right]+2 \mathrm{H}^{+}+\mathrm{e}^{-}
$$

The formation of the ternary ion-association complex can be described by Eq. 4 , in which $\mathrm{BZ}^{+}$is the cation of BZC.

$$
\left[\mathrm{Co}^{\mathrm{III}}\left(\mathrm{L}^{2-}\right)_{2}\right]^{-}+\mathrm{BZ}^{+} \rightleftarrows\left(\mathrm{BZ}^{+}\right)\left[\mathrm{Co}^{\mathrm{III}}\left(\mathrm{L}^{2-}\right)_{2}\right]
$$

The overall process of complex formation and extraction at the optimum $\mathrm{pH}$-range (see Figure 3, curve 2) is shown in Eq. 5.

$$
\begin{aligned}
& \mathrm{Co}_{(\mathrm{aq})}^{\mathrm{II}}+2 \mathrm{HL}^{-}{ }_{(\mathrm{aq})}+\mathrm{BZ}^{+}(\mathrm{aq}) \rightleftarrows \\
& \rightleftarrows\left(\mathrm{BZ}^{+}\right)\left[\mathrm{Co}^{\mathrm{III}}\left(\mathrm{L}^{2-}\right)_{2}\right]_{(\mathrm{org})}+2 \mathrm{H}^{+}{ }_{(\mathrm{aq})}+\mathrm{e}^{-}
\end{aligned}
$$

It involves metal assisted deprotonation of the ligand $\mathrm{HL}^{-}$, oxidation of the initially formed labile $\mathrm{Co}^{\mathrm{II}}$-complex to inert $\mathrm{Co}^{\mathrm{III}}$-complex in the presence of air, ${ }^{16,58,63}$ and ion-association between $\mathrm{BZ}^{+}$and the anionic complex..$^{54,64}$ The spectral characteristics and composition of the ternary complex (Co:MTAR:BZC = 1:2:1), and the optimal $\mathrm{pH}$ range of its existence suggests that it contains two deprotonated ligands, as in the literature concerning similar ternary PAR- and TAR-complexes. ${ }^{27-31}$ These azo dyes have $\mathrm{p} K_{\mathrm{a}}$ values (Table 2) that are close to those reported for MTAR.

\section{5. Extraction Characteristics}

The conditional equilibrium constant characterizing Eq. 5 was calculated by the mobile equilibrium method $^{53}$ (Figure 8), Likussar-Boltz method ${ }^{67}$ (Figure 9) and Holme-Langhmyir method. ${ }^{68}$ The obtained values are given in Table 3, along with the values for fraction extracted $(E)$ and distribution ratio $(D)$.

Table 3. Extraction characteristics.

\begin{tabular}{lc}
\hline Extraction characteristic & Value \\
\hline & $5.6 \pm 0.2^{\mathrm{a}}(N=3)$ \\
Extraction constant $\left(\log K_{\mathrm{ex}}\right)$ & $5.7 \pm 0.3^{\mathrm{a}}(N=5)$ \\
& $5.8 \pm 0.1^{\mathrm{c}}(N=5)$ \\
Distribution ratio $(\log D)$ & $1.4 \pm 0.2(N=4)$ \\
Fraction extracted $(E), \%$ & $96 \pm 2(N=4)$ \\
\hline
\end{tabular}

${ }^{a}$ Likussar-Boltz method. ${ }^{b}$ Molar equilibrium method. ${ }^{\mathrm{c}}$ HolmeLangmyhr method.

\section{6. Beer's Law and Analytical Characteristics}

The relationship between the concentration of $\mathrm{Co}^{\mathrm{II}}$ in the aqueous phase and the absorbance of the extracted ternary complex was studied under optimum conditions (Table 1). A good linearity was observed in the concentration range of $0.2-2.8 \mu \mathrm{g} \mathrm{cm}^{-3}\left(R^{2}=0.9994, N=7\right)$. The linear regression equation was $A=0.395 \gamma+0.004$, where $A$ is the absorbance and $\gamma$ is the concentration $\left(\mu \mathrm{g} \mathrm{cm}^{-3}\right)$. The standard deviations of the slope and intercept were

Table 2. Dissociation constants of MTAR, TAR and PAR.

\begin{tabular}{lccccc}
\hline Azo dye & $\mathbf{p} K_{\mathbf{N H}}$ & $\begin{array}{c}\mathbf{p} K_{\mathbf{a}} \\
\mathbf{p} K_{\mathbf{p}-\mathrm{OH}}\end{array}$ & $\mathbf{p} K_{\mathbf{o}-\mathrm{OH}}$ & Conditions & Ref. \\
\hline MTAR & - & 5.7 & 11.8 & & 62 \\
TAR & 1.25 & 6.0 & 9.3 & $0.1 \mathrm{~mol} \mathrm{dm}^{-3} \mathrm{NaC1O}_{4}$ & 65,66 \\
& 0.96 & 6.23 & 9.44 & $0.1 \mathrm{~mol} \mathrm{dm}^{-3} \mathrm{NaClO}_{4}$ & \\
& - & 6.16 & 9.59 & $\mathrm{I}=0.2$ & \\
PAR & - & 6.15 & 9.68 & & \\
& 2.7 & 5.83 & 12.5 & $0.1 \mathrm{~mol} \mathrm{dm}^{-3} \mathrm{KNO}_{3}$ & 65,66 \\
& 2.66 & 5.48 & 12.31 & $0.1 \mathrm{~mol} \mathrm{dm}^{-3} \mathrm{NaC}_{4}$ & \\
& 3.1 & 5.6 & 11.9 & $\mathrm{I}=0.1$ & \\
\hline
\end{tabular}


0.004 and 0.008 , respectively. The limits of detection (LOD) and quantitation (LOQ), calculated as 3- and 10 times standard deviation of the intercept divided by the slope, were $\mathrm{LOD}=0.058 \mu \mathrm{g} \mathrm{cm}^{-3}$ and $\mathrm{LOQ}=0.193 \mu \mathrm{g} \mathrm{cm}^{-3}$. The molar absorptivity $(\varepsilon)$ and Sandell's sensitivity $(S S)$ were $\varepsilon=2.33 \times 10^{4} \mathrm{dm}^{3} \mathrm{~mol}^{-1} \mathrm{~cm}^{-1}$ and $S S=2.53 \times 10^{-3} \mu \mathrm{g}$ $\mathrm{cm}^{-2}$, respectively.

\section{Conclusions}

The present investigations shed light on the complex formation of $\mathrm{Co}^{\mathrm{II}}$ with MTAR in the presence or absence of BZC. The conditions for formation of two electroneutral complex species, $\left[\mathrm{Co}^{\mathrm{III}} \mathrm{L}(\mathrm{HL})\right]$ and $\left(\mathrm{BZ}^{+}\right)\left[\mathrm{Co}^{\mathrm{III}}(\mathrm{L})_{2}\right]$, were found. The first one contains one monoprotonated MTAR and one deprotonated MTAR. It is extracted in a narrow $\mathrm{pH}$-range (about 5.5) and shows an absorption maximum at $509 \mathrm{~nm}$. In the presence of BZC, a ternary ion-association complex $\left(\lambda_{\max }=550 \mathrm{~nm}\right)$ is formed over a wider $\mathrm{pH}$ range (6.8-8.7). In both cases, the complex formation involves the oxidation of $\mathrm{Co}^{\mathrm{II}}$ to $\mathrm{Co}^{\mathrm{III}}$ by atmospheric oxygen.

\section{Acknowledgements}

This study is part of a project (DPDP-24) within the framework of a scientific competition "Doctoral and postdoctoral projects-2019" at the Medical University of Plovdiv.

\section{References}

1. K. K. Chatterjee, Uses of Metals and Metallic Minerals, New Age International (P) Ltd. Publishers, New Delhi, India, 2007, pp. 272-275.

2. S. Gialanella, A. Malandruccolo, Aerospace Alloys, Springer, Cham, Switzerland, 2020, pp. 267-386.

DOI:10.1007/978-3-030-24440-8_6

3. T. Wilson, We'll all be relying on Congo to power our electric cars, https://www.bloomberg.com/news/articles/2017-10-26/ battery-boom-relies-on-one-african-nation-avoiding-chaosof-past, (assessed: March 31, 2020)

4. G. M. Mudd, Z. Weng, S. M. Jowitt, I. Turnbull, T. Graedel, Ore Geol. Rev. 2013, 55, 87-98.

DOI:10.1016/j.oregeorev.2013.04.010

5. G. Rao, Nickel and Cobalt Ores: Flotation, in: Reference Module in Chemistry, Molecular Sciences and Chemical Engineering, Elsevier, 2014, pp. 1-27.

DOI:10.1016/B978-0-12-409547-2.10944-8

6. D. Linhares, A. Pimentel, C. Borges, J. V. Cruz, P. Garcia, A. dos Santos Rodrigues, Sci. Total Environ. 2019, 684, 715-721. DOI:10.1016/j.scitotenv.2019.05.359

7. S. J. Moore, M. J. Mayer, R. Biedendieck, E. Deery, M. J. Warren, New Biotechnol. 2014, 31, 553-561.

DOI:10.1016/j.nbt.2014.03.003
8. A. Z. Zalov, Sh. A. K. Ibragimova, Izv. Saratov Univ. (N. S.), Ser. Chemistry. Biology. Ecology, 2019, 19, 379-386 (in Russian). DOI:10.18500/1816-9775-2019-19-4-379-386

9. L. Dospatliev, M. Ivanova, Bulg. Chem. Commun. 2017, 49, 787-791.

10. L. Dospatliev, Z. Yaneva, Sci. Technol. 2014, 4, 31-35.

11. A. Z. Zalov, K. A. Kuliev, S. M. Shiralieva, S. A. Mammadova, K. R. Aliyeva, S. N. Gahramanova, J. Pharmacogn. Phytochem. 2019, 8, 2612-2616.

12. T. Yotsuyanagi, R. Yamashita, K. Aomura, Jpn. Anal. 1970, 19, 981-982. DOI:10.2116/bunsekikagaku.19.981

13. R. Yamashita, T. Yotsuyanagi, K. Aomura, Jpn. Anal. 1971, 20, 1282-1288. DOI:10.2116/bunsekikagaku.20.1282

14. H. Okochi, Jpn. Anal. 1972, 21, 51-56. DOI:10.2116/bunsekikagaku.21.51

15. S. G. Mamuliya, I. V. Pyatnitskii, L. L. Kolomiets, K. I. Grigalashvili, Zh. Anal. Khim. 1980, 35, 1306-1309.

16. T. Okutani, A. Sakuragawa, M. Murakami, Anal. Sci. 1991, 7, 109-112. DOI:10.2116/analsci.7.Supple_109

17. A. G. Gaikwad, H. Noguchi, M. Yoshio, Anal. Lett. 1991, 24, 1625-1641. DOI:10.1080/00032719108052999

18. J. Dolezal and L. Sommer, Collection Czech. Chem. Commun. 1994, 59, 2209-2226. DOI:10.1135/cccc19942209

19. S. N. Bhadani, M. Tewari, A. Agrawal, C. Sekhar, J. Indian Chem. Soc. 1998, 75, 176-177.

20. K. Sato, T. Goto, Jpn. Anal. 1998, 47, 735-738. DOI:10.2116/bunsekikagaku.47.735

21. P. Berton, R. G. Wuilloud, Anal. Methods 2011, 3, 664-672. DOI:10.1039/c0ay00616e

22. M. H. Hosseini, F. Kaveh, H. Haddadi, E. Zolfonoun, Sep. Sci. Technol. 2017, 52, 2632-2640. DOI:10.1080/01496395.2017.1301955

23. M. A. Akl, W. S. Alharawi, Egypt. J. Chem. 2018, 61, 639-650. DOI:10.21608/ejchem.2018.3586.1300

24. K. Ueda, Bull. Chem. Soc. Jpn. 1979, 52, 1215-1216. DOI:10.1246/bcsj.52.1215

25. M. Soylak, E. Yilmaz, J. Hazard. Mater. 2010, 182, 704-709. DOI:10.1016/j.jhazmat.2010.06.089

26. V. Divarova, K. Stojnova, P. Racheva, V. Lekova, Russ. J. Inorg. Chem. 2018, 63, 974-977. DOI:10.1134/S0036023618070057

27. V. V. Divarova, P. V. Racheva, V. D. Lekova, K. B. Gavazov, A. N. Dimitrov, J. Chem. Technol. Metall. 2013, 48, 623-630.

28. M. Široki, L. Marić, Z. Štefanac, M. J. Herak, Anal. Chim. Acta 1975, 75, 101-109. DOI:10.1016/S0003-2670(01)81957-7

29. L. Marić, M. Široki, Z. Štefanac, M. J. Herak, J. Inorg. Nucl. Chem. 1981, 43, 3357-3361. DOI:10.1016/0022-1902(81)80115-7

30. P. V. Racheva, K. B. Gavazov, V. D. Lekova, A. N. Dimitrov, J. Mater. 2013, 2013, 7. DOI:10.1155/2013/897343

31. V. V. Divarova, K. B. Gavazov, V. D. Lekova and A. N. Dimitrov, Chemija 2013, 24, 81-87.

32. V. V. Divarova, V. D. Lekova, P. V. Racheva, K. T. Stojnova, A. N. Dimitrov, Acta Chim. Slov. 2014, 61, 813-818.

33. V. Divarova, K. Stojnova, P. Racheva, V. Lekova, Acta Chim. Slov. 2016, 63, 97-103. DOI:10.17344/acsi.2015.1987 
34. J. B. Noffsinger, N. D. Danielson, J. Liq. Chromatogr. 1986, 9, 2165-2183. DOI:10.1080/01483918608074141

35. H. R. Pouretedal, P. Sononi, M. H. Keshavarz, A. Semnani, Chemistry 2009, 18, 22-34.

36. K. Ueda, Analytical Letters 1978, 11, 1009-1021. DOI:10.1080/00032717808067896

37. Y. Erdogdu, Ü. C. Başköse, S. Sağlam, Chem. Pap. 2019, 73, 1879-1891. DOI:10.1007/s11696-019-00739-4

38. K. B. Gavazov, T. S. Stefanova, Croat. Chem. Acta 2014, 87, 233-240. DOI:10.5562/cca2436

39. K. B. Gavazov, V. B. Delchev, K. T. Mileva, T. S. Stefanova, G. K. Toncheva, Acta Chim. Slov. 2016, 63, 392-398. DOI:10.17344/acsi.2016.2431

40. G. K. Toncheva, N. P. Milcheva, K. B. Gavazov, Acta Chim. Slov. 2018, 65, 847-852. DOI:10.17344/acsi.2018.4491

41. D. G. Hristov, N. P. Milcheva, K. B. Gavazov, Acta Chim. Slov. 2019, 66, 987-994. DOI:10.17344/acsi.2019.5244

42. K. B. Gavazov, V. B. Delchev, N. P. Milcheva, G. K. Toncheva, Open Chem. 2019, 17, 599-608.

DOI:10.1515/chem-2019-0071

43. G. K. Toncheva, D. G. Hristov, N. P. Milcheva, K. B. Gavazov, Acta Chim. Slov. 2020, 67, 151-158.

DOI:10.17344/acsi.2019.5299

44. N. N. Kiryukhina, Tr. Perm. Med. Inst. 1972, 108, 178-181.

45. Y. Chung, W. Chung, Bull. Korean Chem. Soc. 2003, 24, 17811784. DOI:10.5012/bkcs.2003.24.12.1781

46. L. Mastropasqua, L. Agnifili, R. Mastropasqua, V. Fasanella, Curr. Opin. Pharmacol. 2013, 13, 56-64.

DOI:10.1016/j.coph.2012.10.002

47. R. C. Rowe, P. Sheskey, M. Quinn (Ed.): Handbook of pharmaceutical excipients, Pharmaceutical Press, London, UK, 2009, pp. 56-58

48. J. Halvax, G. Wiese, J. Arp, J. Vermeer, W. Van Bennekom, A. Bult, J. Pharmaceut. Biomed. Anal. 1990, 8, 243-252.

DOI:10.1016/0731-7085(90)80033-L

49. E. Asmus, Fresenius' J. Anal. Chem. 1960, 178, 104-116. DOI:10.1007/BF00467200

50. H. E. Bent, C. L. French, J. Am. Chem. Soc. 1941, 63, 568-572. DOI:10.1021/ja01847a059
51. M. I. Bulatov, I. P. Kalinkin, Practical Handbook on Photometric Methods of Analysis, Khimiya, Leningrad, Russia, 1976.

52. J. H. Yoe, A. L. Jones, Ind. Eng. Chem. Anal. Ed. 1944, 16, 111-115. DOI:10.1021/i560126a015

53. Z. Zhiming, M. Dongsten, Y. Cunxiao, J. Rare Earths 1997, $15,216-219$.

54. K. B. Gavazov, Liquid-liquid extraction of ion-association complexes, in: J. C. Taylor (Ed.) Advances in Chemistry Research, Vol. 50, Nova Science Publishers, New York, 2019, pp. 203-238.

55. P. Job, Ann. Chim. (Paris) 1928, 9, 113-134. DOI:10.3406/bmsap.1928.9218

56. A. Corsini, Q. Fernando, H. Freiser, Inorg. Chem. 1963, 2, 224-226. DOI:10.1021/ic50005a061

57. T. Iwamoto, M. Fujimoto, Anal. Chim. Acta 1963, 29, 282 284. DOI:10.1016/S0003-2670(00)88616-X

58. K. Mochizuki, T. Imamura, T. Ito, M. Fujimoto, Bull. Chem. Soc. Jpn. 1978, 51, 1743-1750. DOI:10.1246/bcsj.51.1743

59. K. Mochizuki, T. Ito, M. Fujimoto, Bull. Chem. Soc. Jpn. 1979, 52, 441-445. DOI:10.1246/bcsj.52.441

60. V. Cucinotta, R. Caruso, A. Giuffrida, M. Messina, G. Maccarrone, A. Torrisi, J. Chromatogr. A 2008, 1179, 17-23. DOI:10.1016/j.chroma.2007.09.063

61. I. Vyshcherevich, I. Kalinichenko, J. Water Chem. Technol. 2010, 32, 33-38. DOI:10.3103/S1063455X10010042

62. N. Menek, E. Eren, S. Topçu, Dyes Pigm., 2006, 68, 205-210. DOI:10.1016/j.dyepig.2005.01.010

63. X.-Q. Luo, Q.-R. Liu, Y.-J. Han, L.-W. Xue, Acta Chim. Slov. 2020, 67, 159-166. DOI:10.17344/acsi.2019.5303

64. K. Tôei, Anal. Sci. 1987, 3, 479-488. DOI:10.2116/analsci.3.479

65. A. Hulanicki, S. Glab, G. Ackermann, Pure and Applied Chemistry 1983, 55, 1137-1230. DOI:10.1351/pac198355071137

66. K. Pytlakowska, V. Kozik, M. Dabioch, Talanta 2013, 110, 202-228. DOI:10.1016/j.talanta.2013.02.037

67. W. Likussar, D. F. Boltz, Anal. Chem. 1971, 43, 1265-1272. DOI:10.1021/ac60304a006

68. A. Holme, F. J. Langmyhr, Anal. Chim. Acta 1966, 36, 383-391. DOI:10.1016/0003-2670(66)80066-1

\section{Povzetek}

Proučevali smo interakcijo med $\mathrm{Co}^{\mathrm{II}}$ in 5-metil-4-(2-tiazolilazo)-rezorcinolom (MTAR) v zmesi voda-kloroform, v prisotnosti ali odsotnosti benzalkonijevega klorida (BZC) kot kationskega iono-asociacijskega reagenta. Določili smo optimalni $\mathrm{pH}$, koncentracijo reagentov in ekstrakcijski čas za ekstrakcijo Co. V prisotnosti BZC lahko ekstrahirani ionski kelat predstavimo s formulo $\left(\mathrm{BZ}^{+}\right)\left[\mathrm{Co}^{\mathrm{III}}\left(\mathrm{MTAR}^{2-}\right)_{2}\right]$, kjer je MTAR v deprotonirani obliki. Določili smo tudi naslednje ekstrakcijske in spektrofotometrične parametre: absorpcijski maksimum, molarno absorptivnost, Sandellovo občutljivost, mejo detekcije in kvantifikacije, konstanto ekstrakcije, porazdelitveno razmerje in delež ekstrakcije. V odsotnosti BZC je ekstrakcija nepopolna in poteka v ozkem območju $\mathrm{pH}$. Ekstrahirani kelat vsebuje en deprotoniran in en monoprotoniran ligand, $\left[\mathrm{Co}^{\mathrm{III}}\left(\mathrm{MTAR}^{2-}\right)\left(\mathrm{HMTAR}^{-}\right)\right]$.

Except when otherwise noted, articles in this journal are published under the terms and conditions of the Creative Commons Attribution 4.0 International License 